CORRECTION

\title{
Correction: Citizen Science Terminology Matters: Exploring Key Terms
}

\author{
M V Eitzel ${ }^{*}$, Jessica L Cappadonna ${ }^{\dagger}$, Chris Santos-Lang ${ }^{\ddagger}$, Ruth Ellen Duerr ${ }^{\S}$, Arika \\ Virapongse§, Sarah Elizabeth West", Christopher Conrad Maximillian Kyba", Anne \\ Bowser $^{* *}$, Caren Beth Cooper ${ }^{\dagger+}$, Andrea Sforzi ${ }^{\ddagger \neq}$, Anya Nova Metcalfe ${ }^{\S 5}$, Edward S

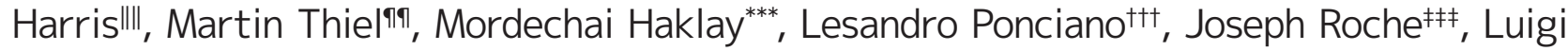

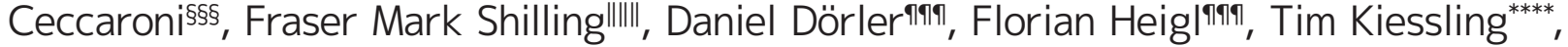

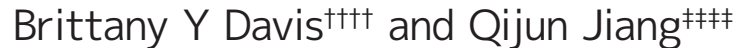

This article details a correction to the article: Eitzel, M V, et al. (2017). Citizen Science Terminology Matters: Exploring Key Terms. Citizen Science: Theory and Practice, 2(1), p. 1. DOI: https://doi.org/10.5334/ cstp.96

Keywords: crowdsourcing; community-based participatory research; epistemology; public participation in science and research; ontology; participatory action research

\section{Correction}

Soon after publication the authors were made aware of an error within Table 3 of the original publication. The example given as the 'Scientist' term 'Citizen scientist, Scientist-citizen, public scientist, community scientist' previously read: "Citizen scientists investigated anecdotal evidence to construct hypotheses regarding developmental disorders that members of the public claimed were triggered by a MMR vaccine."

This should have read: "Citizen scientists investigated anecdotal evidence to construct hypotheses regarding developmental disorders that members of the public claimed were triggered by chemical pollution."

The corrected Table $\mathbf{3}$ is presented here.

\footnotetext{
* Science and Justice Research Center, University of California Santa Cruz, 1156 High St, Santa Cruz, CA 95064, US

Queensland University of Technology S Block, Level 10, Room 1002, Gardens Point Campus, Brisbane, Queensland, AU

₹ Citizen Science Belleville, US

§ Ronin Institute for Independent Scholarship, US

Stockholm Environment Institute, University of York, UK

" GFZ German Research Centre for Geosciences, DE

** Woodrow Wilson International Center for Scholars, US

tt North Carolina State University and North Carolina Museum of Natural Sciences, US

\#‡ Maremma Natural History Museum, IT

\$s Northern Arizona University, US

IIII Scleroderma Education Project Ltd., 2726 Van Hise Ave, Madison, WI 53705, US
}

\footnotetext{
nq Universidad Católica del Norte, Millennium Nucleus Ecology and Sustainable Management of Oceanic Island (ESMOI), Centro de Estudios Avanzados en Zonas Áridas (CEAZA), CL

*** University College London, UK

ttt Federal University of Campina Grande, BR

执 Trinity College Dublin, IE

$\$ \$ \$ 5900001$ Labs, ES

\|IIII University of California, Davis, US

๓ाף Citizen Science Working Group, Institute of Zoology, University of Natural Resources and Life Sciences, Vienna, AT

**** Universidad Católica del Norte, CL

tttt Allegheny College, US

执 Laboratory of Geo-Information Science and Remote Sensing, Wageningen University and Research, NL

Corresponding author: M V Eitzel (mveitzel@ucsc.edu)
} 
Table 3: Terms describing scientists who work with citizens in 'citizen science.'

\begin{tabular}{|c|c|c|}
\hline 'Scientist' term & Definition & Example \\
\hline $\begin{array}{l}\text { Citizen scientist, } \\
\text { Scientist-citizen, } \\
\text { public scientist, } \\
\text { community } \\
\text { scientist }\end{array}$ & $\begin{array}{l}\text { Individual with formal science } \\
\text { training who is actively } \\
\text { engaged in the civic sphere } \\
\text { and wants their work to both } \\
\text { serve the greater good and } \\
\text { do so transparently (Stilgoe } \\
\text { 2009) }\end{array}$ & $\begin{array}{l}\text { Citizen scientists investigated anecdotal } \\
\text { evidence to construct hypotheses regarding } \\
\text { developmental disorders that members of the } \\
\text { public claimed were triggered by chemical } \\
\text { pollution (Stilgoe 2009). Members of Union of } \\
\text { Concerned Scientists' Science Network (http:// } \\
\text { www.ucsusa.org/science-network) }\end{array}$ \\
\hline Civic educators & $\begin{array}{l}\text { Individual who provides } \\
\text { information and/or creates } \\
\text { educational opportunities } \\
\text { for others with the purpose } \\
\text { of building a path for greater } \\
\text { civic engagement }\end{array}$ & $\begin{array}{l}\text { Researchers, teachers, scientists, issue advo- } \\
\text { cates, journalists, reporters and political } \\
\text { campaigners (Ceccaroni et al. 2016) }\end{array}$ \\
\hline Commercial & $\begin{array}{l}\text { Individual trained in science } \\
\text { with the goal of creating prod- } \\
\text { ucts for profit }\end{array}$ & Commercial fisher, Commercial scientist \\
\hline $\begin{array}{l}\text { Credentialed, } \\
\text { Trained, Educated }\end{array}$ & $\begin{array}{l}\text { Individual with formal scien- } \\
\text { tific degrees and training }\end{array}$ & Faculty member at a university \\
\hline Elite & $\begin{array}{l}\text { Individual with experience } \\
\text { and/or privilege not shared by } \\
\text { the general public }\end{array}$ & $\begin{array}{l}\text { Only elite scientists may serve in some peer- } \\
\text { review processes or are considered for tenure } \\
\text { or funding }\end{array}$ \\
\hline $\begin{array}{l}\text { Institutional, } \\
\text { Academic, } \\
\text { Laboratory }\end{array}$ & $\begin{array}{l}\text { Individual employed by or } \\
\text { affiliated with an academic } \\
\text { institution, agency, company, } \\
\text { or non-governmental organi- } \\
\text { zation }\end{array}$ & $\begin{array}{l}\text { Tenured professor, Government scientist, } \\
\text { Laboratory technician, Student }\end{array}$ \\
\hline $\begin{array}{l}\text { Professional, Paid, } \\
\text { Employed }\end{array}$ & $\begin{array}{l}\text { Individual working in a scien- } \\
\text { tific occupation, profession, or } \\
\text { holding a position for which } \\
\text { they are paid }\end{array}$ & White collar professional, Professor, Employee \\
\hline Researcher & $\begin{array}{l}\text { Individual investigating a spe- } \\
\text { cific and identified scientific } \\
\text { question }\end{array}$ & Research scientist, Research ecologist \\
\hline Scientist-activist & $\begin{array}{l}\text { Individual with formal science } \\
\text { training who applies their } \\
\text { expertise to political agendas }\end{array}$ & $\begin{array}{l}\text { Internationally, thousands of scientists } \\
\text { participated in a "March for Science" on April } \\
22,2017 \text { to show support for evidence-based } \\
\text { policies in government }\end{array}$ \\
\hline $\begin{array}{l}\text { Volunteer } \\
\text { Scientist }\end{array}$ & $\begin{array}{l}\text { An individual who is not } \\
\text { paid for their participation in } \\
\text { scientific pursuits }\end{array}$ & Graduate students \\
\hline
\end{tabular}

Caveat

'Citizen Scientist' is easily confused with more common meaning of public involvement in science

Closely associated with democratic values, inherently politically laden

Incentivized by financial profit, rather than 'knowledge for the sake of knowledge'

Reinforces the value of formal scientific education

Typically excludes the general public, earlycareer scientists, and minorities; many scientists strive not to be elitist

Scientists may not be affiliated with an institution or may not work in a laboratory

Some scientists may conduct participatory projects outside paid time

Researchers are often interpreted strictly as academics

Can be perceived as having shed the 'objectivity' of science

Implies that scientist is inexperienced or not worth formally hiring

\section{Competing Interests}

The authors have no competing interests to declare.

\section{References}

Eitzel, M.V., Cappadonna, J.L., Santos-Lang, C., Duerr, R.E., Virapongse, A., West, S.E., Kyba, C.C.M.,
Bowser, A., Cooper, C.B., Sforzi, A., Metcalfe, A.N., Harris, E.S., Thiel, M., Haklay, M., Ponciano, L., Roche, J., Ceccaroni, L., Shilling, M., Döler, D., Heigl, F., Kiessling, T., Davis, B.Y. and Jiang, Q. 2017. Citizen Science Terminology Matters: Exploring Key Terms. Citizen Science: Theory and Practice, 2(1). DOI: https://doi.org/10.5334/cstp.96 
How to cite this article: Eitzel, M V, Cappadonna, J L, Santos-Lang, C, Duerr, R E, Virapongse, A, West, S E, Kyba, C C M, Bowser, A, Cooper, C B, Sforzi, A, Metcalfe, A N, Harris, E S, Thiel, M, Haklay, M, Ponciano, L, Roche, J, Ceccaroni, L, Shilling, F M, Dörler, D, Heigl, F, Kiessling, T, Davis, B Y and Jiang, Q 2017 Correction: Citizen Science Terminology Matters: Exploring Key Terms. Citizen Science: Theory and Practice, 2(1): 2, pp.1-3, DOI: https://doi.org/10.5334/cstp.113

Submitted: 16 June 2017 Accepted: 16 June 2017 Published: 22 June 2017

Copyright: (c) 2017 The Author(s). This is an open-access article distributed under the terms of the Creative Commons Attribution 4.0 International License (CC-BY 4.0), which permits unrestricted use, distribution, and reproduction in any medium, provided the original author and source are credited. See https://creativecommons.org/licenses/by/4.0/.

$\mathrm{u}[\mathrm{C}$ Citizen Science: Theory and Practice is a peer-reviewed open access journal published by 